\title{
Contents of Volume 110 (1995)
}

\section{Authors and Titles}

BARBOUR, RICHMOND (Oregon State Univ.). "When I Acted Young Antinous": Boy Actors and the Erotics of

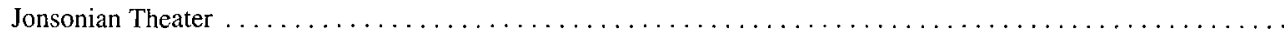
BERGNER, GWEN (Princeton Univ.). Who Is That Masked Woman? or, The Role of Gender in Fanon's Black Skin,

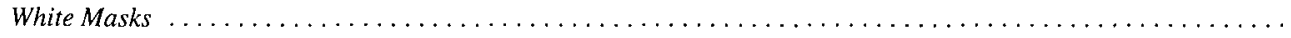
BERLANT, LAUREN (Univ. of Chicago), and MICHAEL WARNER (Rutgers Univ., New Brunswick). Guest column. What Does Queer Theory Teach Us about $X$ ? (Oct.) 1006 (Jan.) 75 (May) 343

BLANK, PAULA (Coll. of William and Mary). Comparing Sappho to Philaenis: John Donne's "Homopoetics" ....... BOONE, JOSEPH A. (Univ. of Southern California). Vacation Cruises; or, The Homoerotics of Orientalism ........ CHINITZ, DAVID (Loyola Univ., Chicago). T. S. Eliot and the Cultural Divide $\ldots \ldots \ldots \ldots \ldots \ldots \ldots \ldots \ldots$ COLAS, SANTIAGO (Univ. of Michigan, Ann Arbor). Of Creole Symptoms, Cuban Fantasies, and Other Latin Ameri-

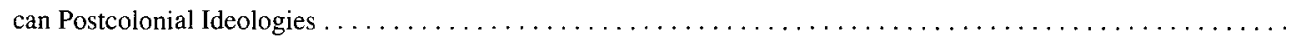
DHARWADKER, APARNA (Univ. of Oklahoma). Historical Fictions and Postcolonial Representation: Reading Girish

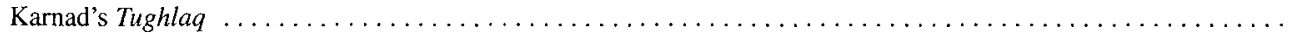
FOSTER, THOMAS (Indiana Univ., Bloomington). Circles of Oppression, Circles of Repression: Etel Adnan's Sitt

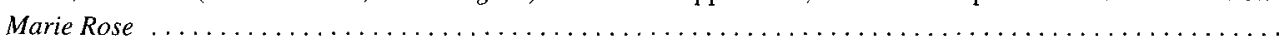

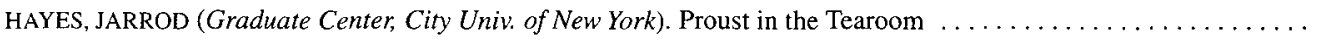
HUTCHEON, LINDA (Univ. of Toronto, Saint George Campus). Introduction. Colonialism and the Postcolonial Condi-

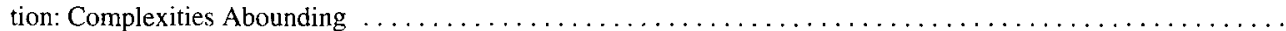
JEFFREYS, MARK (Univ. of Alabama, Birmingham). Ideologies of Lyric: A Problem of Genre in Contemporary Anglophone Poetics

JOLLY, ROSEMARY (Queen's Univ.). Rehearsals of Liberation: Contemporary Postcolonial Discourse and the New

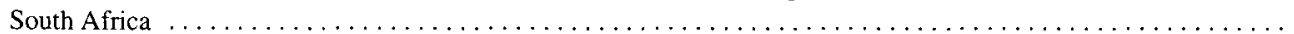
KIBBIE, ANN LOUISE (Bowdoin Coll.). Monstrous Generation: The Birth of Capital in Defoe's Moll Flanders and

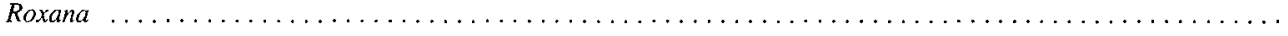
KINOSHITA, SHARON (Univ. of California, Santa Cruz). Heldris de Cornuälle's Roman de Silence and the Feudal Politics of Lineage KORTENAAR, NEIL TEN (Concordia Univ., Sir George Williams Campus). Beyond Authenticity and Creolization:



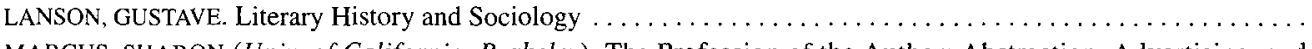
MARCUS, SHARON (Univ. of California, Berkeley). The Profession of the Author: Abstraction, Advertising, and

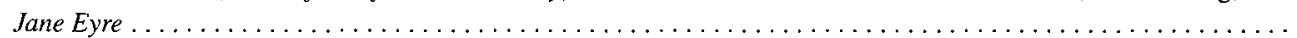
MOHANTY, SATYA P. (Cornell Univ.). Epilogue. Colonial Legacies, Multicultural Futures: Relativism, Objectivity,

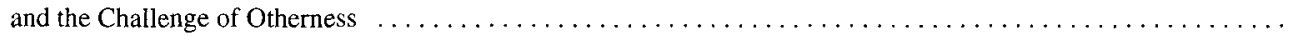

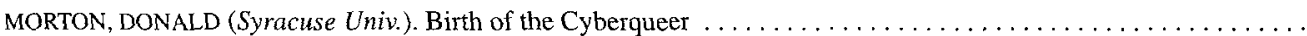
RUMRICH, JOHN (Univ. of Texas, Austin). Milton's God and the Matter of Chaos $\ldots \ldots \ldots \ldots \ldots \ldots \ldots \ldots$ SPACKS, PATRICIA MEYER (Univ. of Virginia). Presidential Address 1994. Reality_Our Subject and Discipline .... THOMAS, DAVID WAYNE (Univ. of California, Davis). Gödel's Theorem and Postmodern Theory . . ............ WARNER, MICHAEL. See BERLANT, LAUREN, and MICHAEL WARNER. 


\section{Miscellaneous}

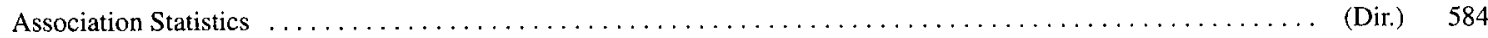

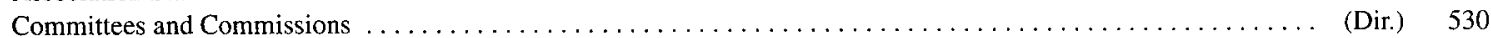

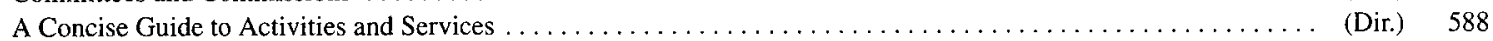

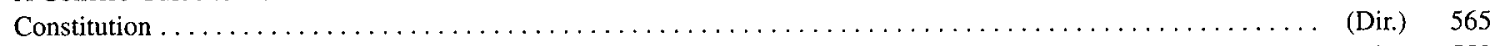

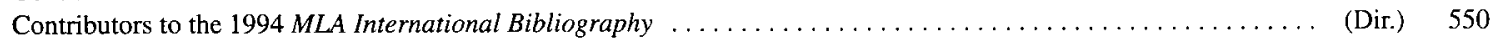

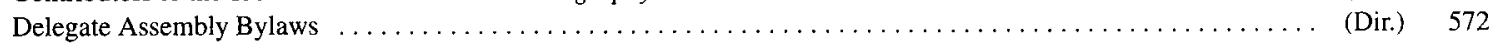

Departmental Administrators

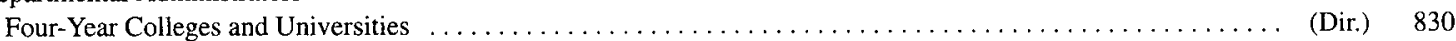

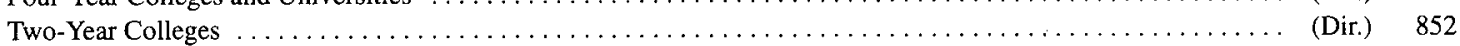

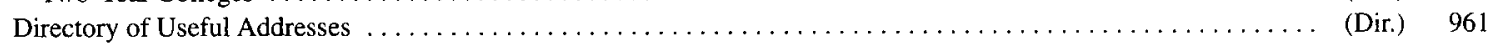

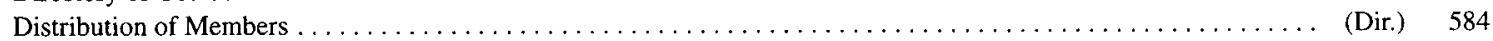

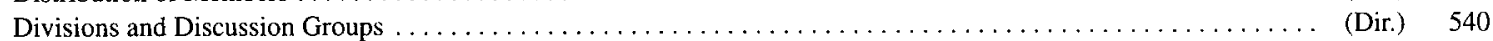

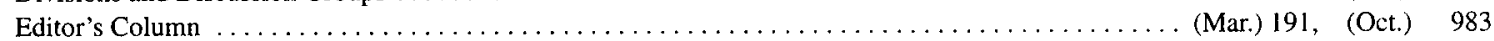

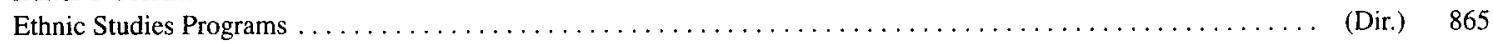

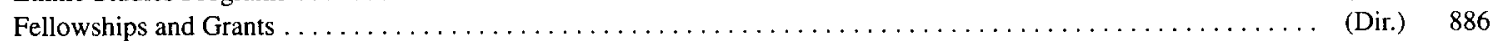

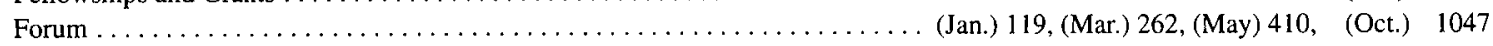

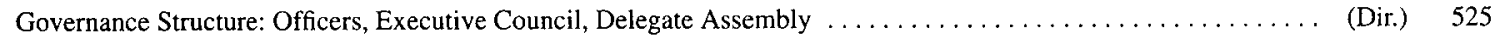

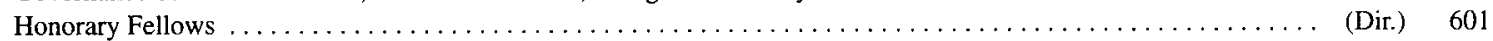

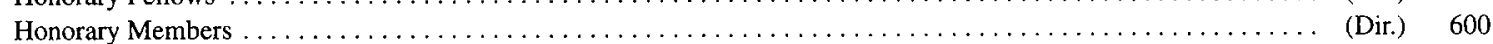

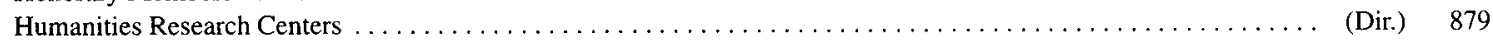

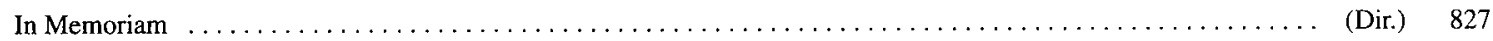

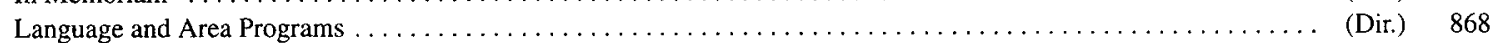

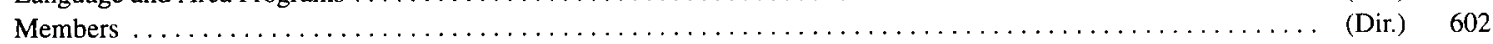

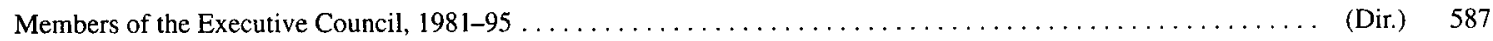

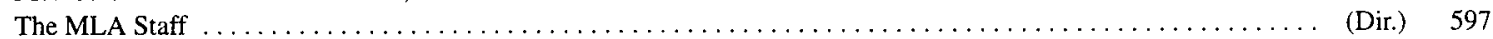



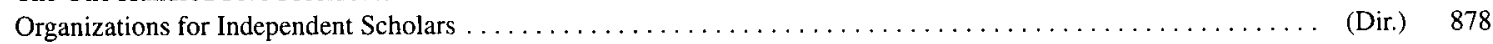

Policies for Divisions, Discussion Groups, and Allied and Affiliate Organizations $\ldots \ldots \ldots \ldots \ldots \ldots \ldots \ldots$ (Dir.) 559

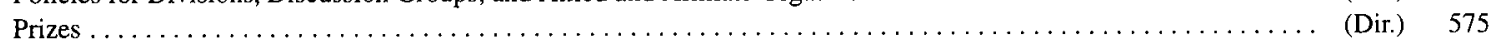

Procedures for Organizing Meetings at the MLA Convention $\ldots \ldots \ldots \ldots \ldots \ldots \ldots \ldots \ldots \ldots \ldots \ldots \ldots \ldots \ldots \ldots$ (Dir.) 552

Professional Notes and Comment . . . . . . . . . . . . . . . . . . (Jan.) 150, (Mar.) 290, (May) 454, (Dir.) 905, (Oct.) 1080

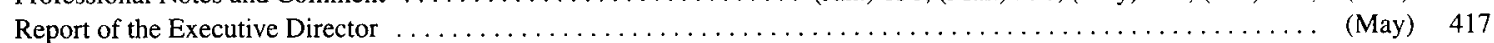

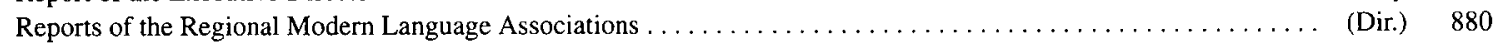

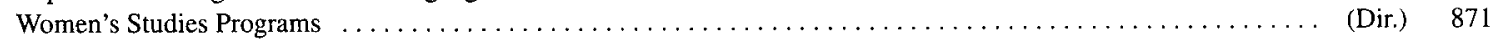




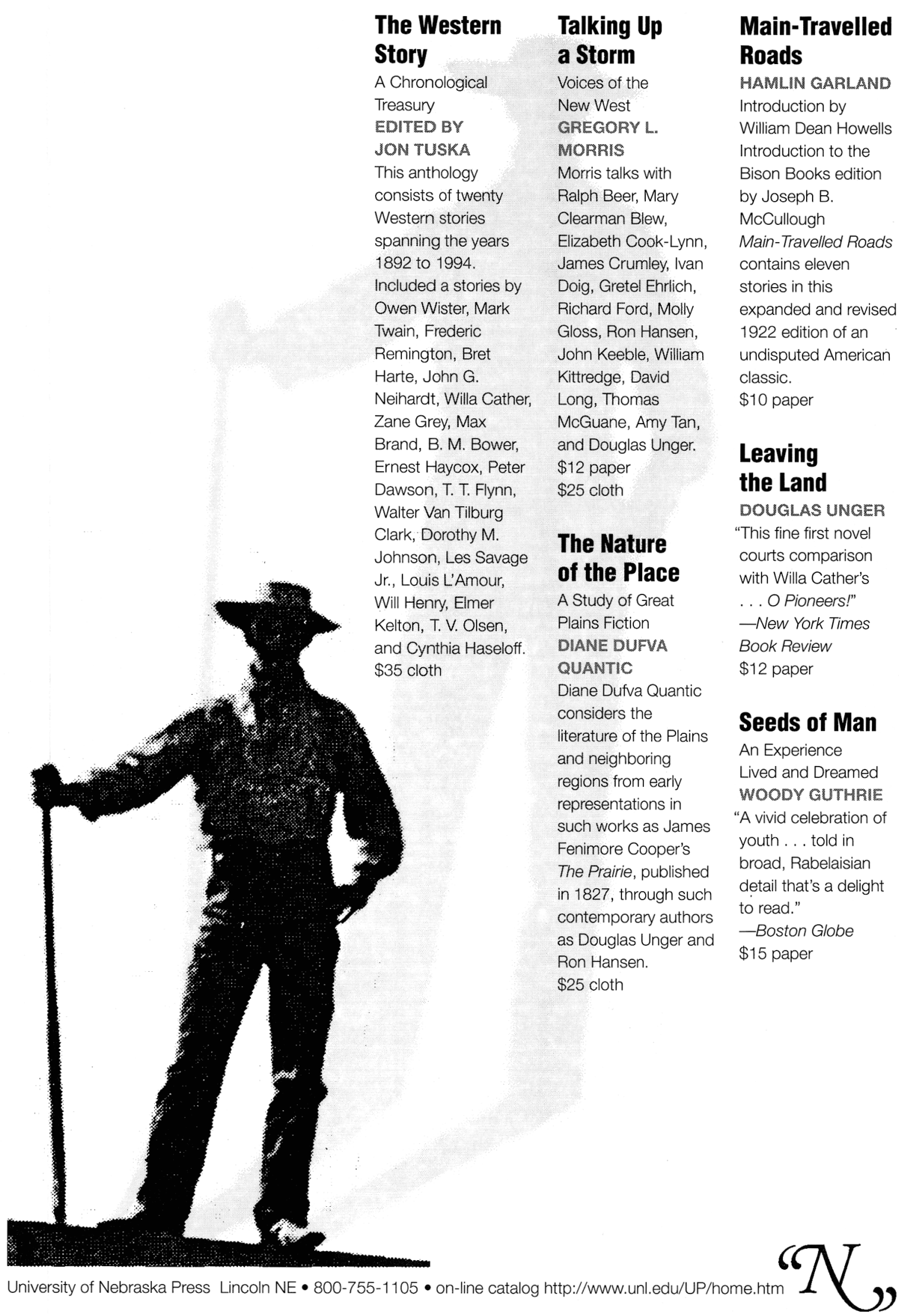




\section{Fust Published!}

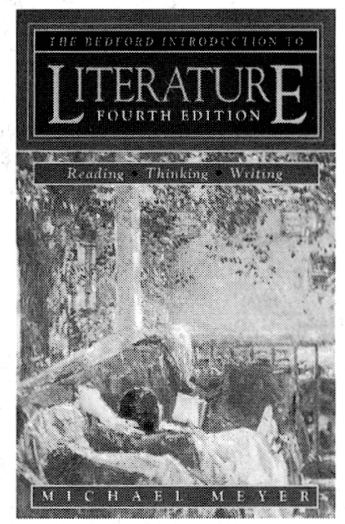

Fall 1995/clothbound 2240 pages $/ \mathbf{\$ 2 9}$ net

Spiral-bound Instructor's Manual/Poetry Audiotape

\section{THE BEDFORD INTRODUCTION}

\section{TO LITERATURE}

Reading, Thinking, and Writing

Fourth Edition

Michael Meyer, University of Connecticut

new edition of the best-selling 3-genre anthology introduced in the last 10 years 57 stories ( 15 new), 436 poems (105 new), and 22 plays (6 new) - expanded coverage of writing about literature - integrated throughout with new chapters on writing about fiction, poetry, and drama and 12 sample papers $\square$ in-depth coverage of 8 writers, including Langston Hughes (new) - expanded albums of world and contemporary literature $\mathbf{m e n e r o u s}$ selection of works by women and minority writers 176 (37 new) Perspectives - secondary biographical and critical materials a strengthened coverage of literary theory throughout $\boldsymbol{\square}$ new glossary of literary terms

"In this anthology both instructor and student encounter an unsurpassed range of significant texts, imaginatively selected and perceptively introduced. It sets the standard against which all similar collections must be measured." - John Glavin, Georgetown University

Now available with any volume in the Case Studies in Contemporary Criticism series at a special price!

Titles Include:

WUTHERING HEIGHTS

Emily Brontë

THE AWAKENING

Kate Chopin

HEART OF DARKNESS

Joseph Conrad

GREAT EXPECTATIONS

Charles Dickens

THE SCARLET LETTER

Nathaniel Hawthorne

THE TURN OF THE SCREW

Henry James

THE DEAD

James Joyce
A PORTRAIT OF THE ARTIST AS A YOUNG MAN

James Joyce

HAMLET

William Shakespeare

FRANKENSTEIN

Mary Shelley

GULLIVER'S TRAVELS

Jonathan Swift

THE HOUSE OF MIRTH

Edith Wharton

Also Available:

Mark Twain

HUCKLEBERRY FINN

A Case Study in Critical Controversy

Edited by Gerald Graff and James Phelan

\section{Bedford Books of St. Martin's Press For exam copies, call 1-800-446-8923}

